\title{
Analysis of Goat Milk by Near-Infrared Spectroscopy
}

\author{
M. DRAČKOVÁ ${ }^{1}$, L. HADRA ${ }^{2}$, B. JANŠTOVÁ ${ }^{1}$, P. NAVRÁTILOVÁ ${ }^{1}$, H. PŘIDALOVÁ ${ }^{1}$, L. VORLOVÁ $^{1}$ \\ ${ }^{1}$ Department of Milk Hygiene and Technology, Faculty of Veterinary Hygiene and Ecology, University of \\ Veterinary and Pharmaceutical Sciences Brno, Czech Republic \\ ${ }^{2}$ Bioveta, a.s., Ivanovice na Hané, Czech Republic
}

Received September 6, 2007

Accepted March 13, 2008

\begin{abstract}
Dračková M., L. Hadra, B. Janštová, P. Navrátilová, H. Přidalová, L. Vorlová: Analysis of Goat Milk by Near-Infrared Spectroscopy. Acta Vet. Brno 2008, 77: 415-422.

The objective of this study was to determine protein, fat, lactose, total solids, non-fatty solids contents, freezing point, titratable acidity and $\mathrm{pH}$ using Fourier transform near infrared spectroscopy (FT-NIR). Sixty samples of goat milk were used to calibrate the instrument by the partial least squares (PLS) method. The spectra were measured on the integration sphere in the reflectance mode with the use of a $0.1 \mathrm{~mm}$ wide transflectance cell. The following statistical values were obtained: correlation coefficient $(R)=0.920$ and standard error of calibration (SEC) $=0.094$ for protein, $R=0.951$ and $\mathrm{SEC}=0.124$ for fat, $R=0.997$ and $\mathrm{SEC}=0.011$ for lactose, $R=0.940$ and $\mathrm{SEC}=0.260$ for total solids, $R=0.873$ and $\mathrm{SEC}=0.159$ for non-fatty solids, $R=$ 0.935 and $\mathrm{SEC}=0.003$ for freezing point, $R=0.952$ and $\mathrm{SEC}=0.295$ for titratable acidity and $R=0.835$ and $\mathrm{SEC}=0.057$ for $\mathrm{pH}$. The calibration models developed were verified by cross validation. The study showed that FT-NIR is a potentially useful technique for evaluating the composition of goat milk.
\end{abstract}

Total solids, protein, fat and sugar content, freezing point, titratable acidity, pH, milk, composition

The quality and composition of goat milk, which is a healthy, wholesome and easily digestible food, depends on a series of factors. These factors are interrelated especially with the breed characteristics, lactation phase, heredity, the animal's individuality, breeding practices, feeding practices, milking method and the health condition of the animals (Aganga et al. 2002).

Traditional methods for the quality assessment of food stuffs (flavour, composition, contamination) are too time-consuming and costly. Several authors thus focused on monitoring the basic food components with near infrared spectroscopy (NIRS). This method has been in use for about 40 years in food stuff analysis (Lee 2004).

NIRS has many properties that rank it among excellent food stuff analysis techniques. It is a physically non-destructive method that has several advantages as compared to the traditional methods. It is rapid, accurate, easily carried out, objective and it can give both quantitative and qualitative results in many component analyses ( $\mathrm{Ru}$ and Glatz 2000; Jankovská and Sustová 2003). NIR spectroscopy is used mostly for the determination of the basic components, i.e. total solids, protein, fat and sugar content. Its applications, however, vary much more and include even the determination of sensory and physicochemical variables, such as density, freezing point, the $\mathrm{pH}$ value etc. ( $\mathrm{Ru}$ and Glatz 2000; Curda et al. 2002).

The use of NIR spectroscopy for monitoring cow and goat milk indicators was focused on by many authors (Jankovská and Šustová 2003; Albanell et al. 1999). The first calibration for the determination of the basic goat milk components was done by DíazCarrillo et al. (1993) and Ru and Glatz (2000). Apart from determining the fat, protein,

Address for correspondence:

MVDr. Michaela Dračková, Ph.D

Department of Milk Hygiene and Technology

University of Veterinary and Pharmaceutical Sciences

Palackého 1/3, 61242 Brno, Czech Republic
Phone: +420541562714

Fax: +420541562 711

E-mail: drackovam@vfu.cz

http://www.vfu.cz/acta-vet/actavet.htm 
lactose and total solid contents and somatic cell counts in goat milk, NIR spectroscopy was used for establishing the total casein, $\alpha$-, $\beta$ - and $\kappa$-casein contents (Díaz-Carrillo et al. 1993).

The objective of our study was to develop calibration models for determining the basic goat milk components using FT-NIR.

\section{Materials and Methods}

Milk samples were collected from White Shorthaired breed goats, kept at a Czech farm. In order to develop calibration models, 60 bulk tank samples of raw goat milk were used. Sampling was done after the kids had been weaned, in the period from the end of April till the beginning of September 2006 at regular time intervals. At the farm, there were 75 goats in their $1^{\text {st }}$ to $8^{\text {th }}$ lactations, the average milk yield being $2-31$ of milk, the average yearly yield 600-800 1 of milk. In the period between mid-May and mid-November, the goats could go on pasture. The feed ration was complemented with $0.5 \mathrm{~kg}$ of hay, a maximum of $1 \mathrm{~kg}$ of grain cereals, vitamin and mineral mixture and a salt block for licking. In the winter, the feed ration contained $3 \mathrm{~kg}$ of grass haylage, $1 \mathrm{~kg}$ of sugar beet silage, $1 \mathrm{~kg}$ of hay and a maximum of $1 \mathrm{~kg}$ of grain cereals, vitamin and mineral mixture and a salt block for licking. Milking was carried out on milking machines twice a day.

In the samples, the following indicators were determined: the contents of protein, fat, lactose, non-fatty solids - all of them on the Bentley 2500 machine (Bentley Instruments, Chaska, USA) based on the Czech National Standard No. 570536 (1999), total solids content (CSN ISO 6731, 1997), titratable acidity and pH levels (ČSN $570530,1972)$. The freezing point was determined based on the Czech National Standard No. 570538 (1998) using a Milk Cryoscope 4D2 machine (Advanced Instruments, Inc., Norwood, USA).

The milk samples were measured with a Nicolet Antaris Near-IR Analyzer (Thermo Electron Corporation, Madison, USA) in the spectral range of $10000-4000 \mathrm{~cm}^{-1}$ with 100 scans. One spectrum analysis time ranged around $1.5 \mathrm{~min}$. The spectra were measured on the integration sphere in the reflectance mode with the use of a transflectance cell $0.1 \mathrm{~mm}$ wide. The samples were warmed up to $40{ }^{\circ} \mathrm{C}$, stirred up and after cooling down to $20{ }^{\circ} \mathrm{C}$, they were transferred onto Petri dishes. The collected data were processed with the TQ Analyst version 6.2.1.509 software using the PLS (partial least square). The same samples were used for cross validation. The results were processed with statistical and graphic software STAT Plus (Matoušková et al. 1992).

\section{Results and Discussion}

A total of 60 bulk tank samples of raw goat milk were used for the development of the calibration models. The ranges of the reference values for the monitored indicators (protein, fat, lactose, total solids, non-fatty solids contents, freezing point, titratable acidity and $\mathrm{pH}$ levels) are presented as standard errors of the mean (Table 1). Samples that displayed an error in the measured spectrum or for which the reference value was established inaccurately were removed using the Spectrum Outlier and Leverage (Table 2) diagnostic device.

The calibration models for all the monitored indicators were developed using a PLS algorithm. In the analyzed samples PLS used spectral as well as concentration information to determine latent variables (PLS factors) in a data set (Tsenkova et al. 2000). In all of the developed calibration models, the maximum number of PLS factors was set at 10 . The highest factor count was found in lactose (10). The lowest PLS factor count (4) was

Table 1. Reference values

\begin{tabular}{|l|c|c|c|c|c|}
\hline Variable & $\mathrm{n}$ & $\mathrm{x}_{\min }$ & $\mathrm{x}_{\max }$ & $\bar{x}$ & $\mathrm{SD}$ \\
\hline Protein [\%] & 60 & 2.33 & 3.41 & 2.81 & 0.23 \\
\hline Fat [\%] & 60 & 2.27 & 5.61 & 3.13 & 0.54 \\
\hline Lactose [\%] & 60 & 4.39 & 4.94 & 4.59 & 0.10 \\
\hline Total solids [\%] & 47 & 10.30 & 13.76 & 11.14 & 0.71 \\
\hline Non-fatty solids contents [\%] & 57 & 7.19 & 8.81 & 7.97 & 0.34 \\
\hline Freezing point $\left[{ }^{\circ} \mathrm{C}\right]$ & 49 & -0.599 & -0.527 & -0.554 & 0.010 \\
\hline Titratable acidity [SH] & 49 & 4.60 & 8.20 & 5.61 & 0.84 \\
\hline pH & 42 & 5.69 & 6.92 & 6.63 & 0.18 \\
\hline
\end{tabular}

$\mathrm{n}$ - samples number, $\bar{x}$ - arithmetic average, $\mathrm{x}_{\min }-$ minimum value, $\mathrm{x}_{\max }$ maximum value, $\mathrm{SD}$ - standard deviation found in the protein content and freezing point. Jankovská and Šustová (2003) obtained 11 PLS factors for lactose content and 14 PLS factors for protein content. Also Díaz-Carrillo et al. (1993) used the PLS method for calibration of basic goat milk components but the samples were measured in transmittance mode. All of the calibration models were developed without spectrum derivation.

The individual calibration 
Table 2. Calibration and validation results

\begin{tabular}{|c|c|c|c|c|c|c|c|c|}
\hline \multirow[b]{2}{*}{ Variable } & \multirow[b]{2}{*}{$\mathrm{n}$} & \multirow[b]{2}{*}{$\begin{array}{l}\text { PLS } \\
\text { factors }\end{array}$} & \multicolumn{3}{|c|}{ calibration } & \multicolumn{3}{|c|}{ validation } \\
\hline & & & $R$ & SEC & $\begin{array}{l}\mathrm{CCV} \\
{[\%]}\end{array}$ & $R$ & SECV & $\begin{array}{l}\mathrm{PCV} \\
{[\%]}\end{array}$ \\
\hline Protein [\%] & 55 & 4 & 0.920 & 0.094 & 3.37 & 0.888 & 0.111 & 3.99 \\
\hline Fat [\%] & 52 & 6 & 0.951 & 0.124 & 4.04 & 0.924 & 0.154 & 5.02 \\
\hline Lactose [\%] & 58 & 10 & 0.997 & 0.011 & 0.24 & 0.935 & 0.050 & 1.09 \\
\hline Total solids [\%] & 41 & 6 & 0.940 & 0.260 & 2.32 & 0.899 & 0.334 & 2.98 \\
\hline Non-fatty solids contents [\%] & 51 & 6 & 0.873 & 0.159 & 2.00 & 0.812 & 0.191 & 2.40 \\
\hline Freezing point $\left[{ }^{\circ} \mathrm{C}\right]$ & 45 & 4 & 0.935 & 0.003 & 0.52 & 0.833 & 0.005 & 0.82 \\
\hline Titratable acidity $[\mathrm{SH}]$ & 49 & 5 & 0.952 & 0.295 & 4.96 & 0.878 & 0.469 & 7.89 \\
\hline $\mathrm{pH}$ & 41 & 7 & 0.835 & 0.057 & 0.85 & 0.703 & 0.076 & 1.14 \\
\hline
\end{tabular}

$\mathrm{n}$ - samples number after removed outlying, $R$ - correlation coefficient, SEC - standard error of calibration, SECV - standard error of validation, CCV - calibration coefficient of variation, PCV - prediction coefficient of variation

correlation coefficients $(R)$ were obtained in the interval from 0.997 for lactose to 0.835 for $\mathrm{pH}$ with the standard errors of calibration (SEC) $0.011 \%$ and 0.057 . The highest standard errors of calibration were found for titratable acidity at $0.295 \mathrm{SH}(R=0.952)$ and total solids at $0.260 \%(R=0.940)$ (Table 2, Figs $1-8)$. Similar results were reported by Díaz-Carrillo et al. (1993) who monitored the contents of protein, total casein, $\alpha-, \beta$ - and $\kappa$-casein, fat and lactose in goat milk using an NIR spectrometer. They found low standard errors and high correlation coefficients: the calibration correlation coefficient was 0.96 for protein, 0.96 for fat and 0.99 for lactose. Their study confirmed also the applicability of NIR spectrometry for determination of casein fractions, even though they were present at low concentrations. Šustová and Kuchtík (2007) showed that when milk samples are measured on Petri dishes, the NIR spectroscopy method is a useful technique for the prediction of fat, true protein, casein and lactose in goat milk. They obtained very high correlation coefficients of calibrations (fat 0.907 , true protein 0.989 , casein 0.890 and lactose 0.981 ).

For the development of a validation model using the cross-validation method, the same set of samples was used as for calibration. Cross-validation confirmed the reliability of the calibration model. The correlation coefficients of the validation $(R)$ were found in the interval of 0.935 for lactose and 0.703 for $\mathrm{pH}$ with the standard errors of calibration and

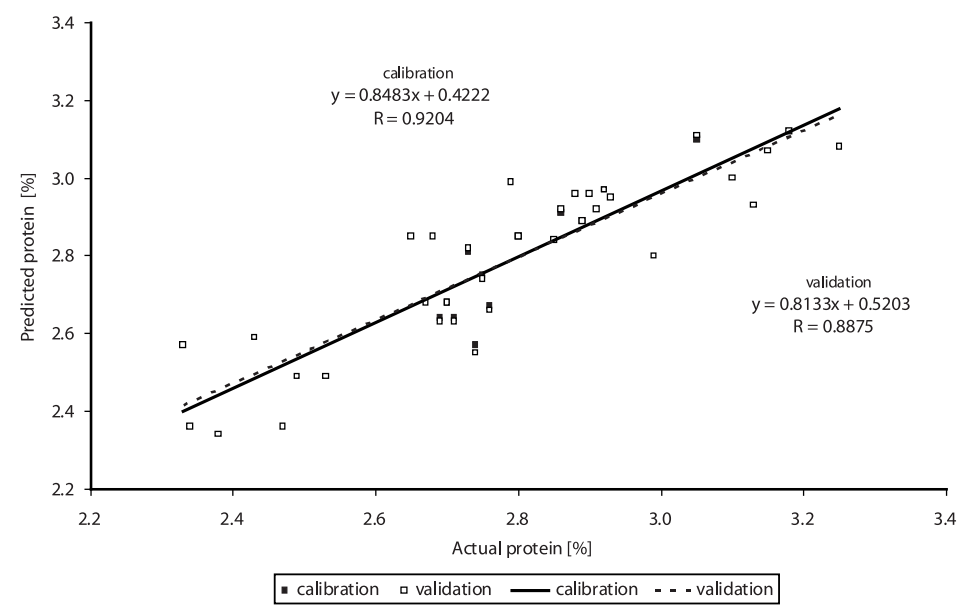

Fig. 1. Calibration and validation models of protein 


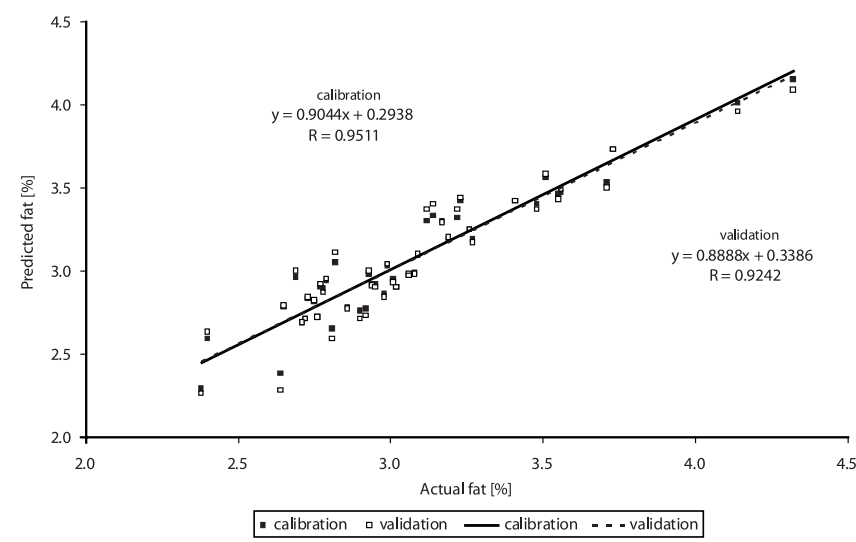

Fig. 2. Calibration and validation models of fat

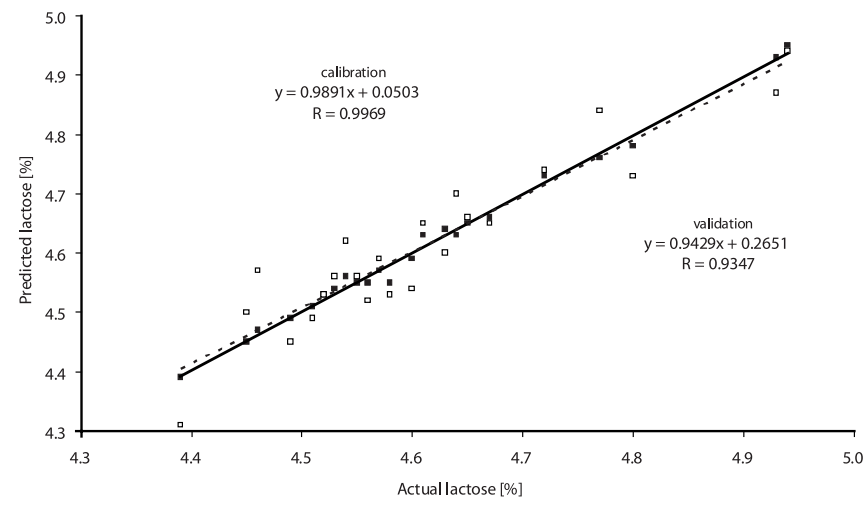

- calibration $\mathrm{\square}$ validation — calibration - - - validation

Fig. 3. Calibration and validation models of lactose

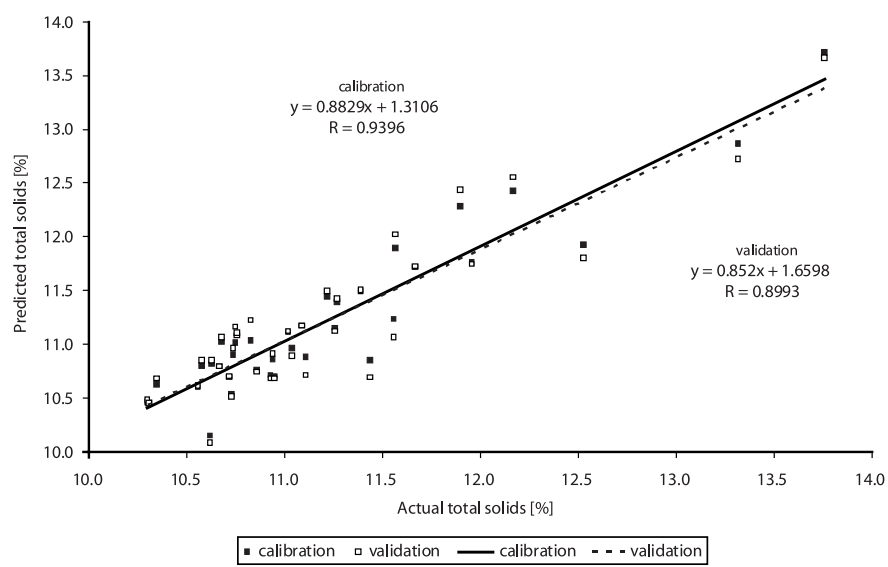

Fig. 4. Calibration and validation models of total solids 


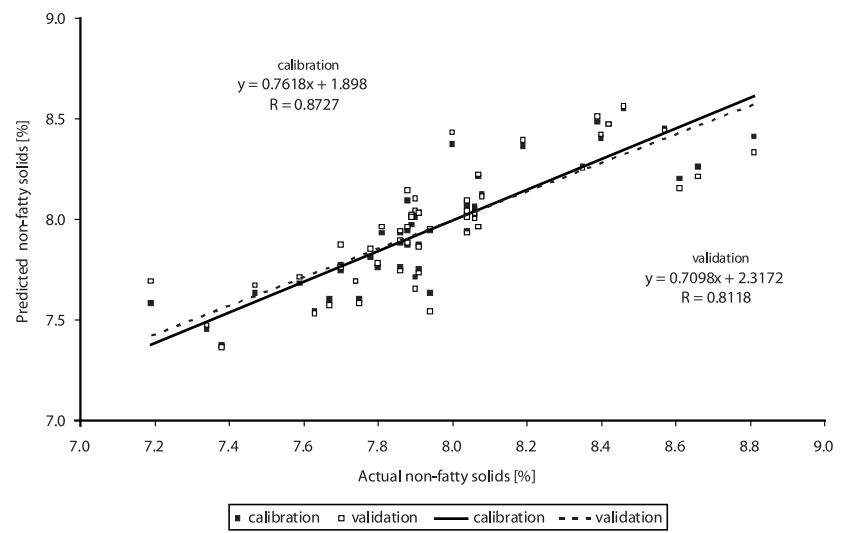

Fig. 5. Calibration and validation models of non-fatty solids

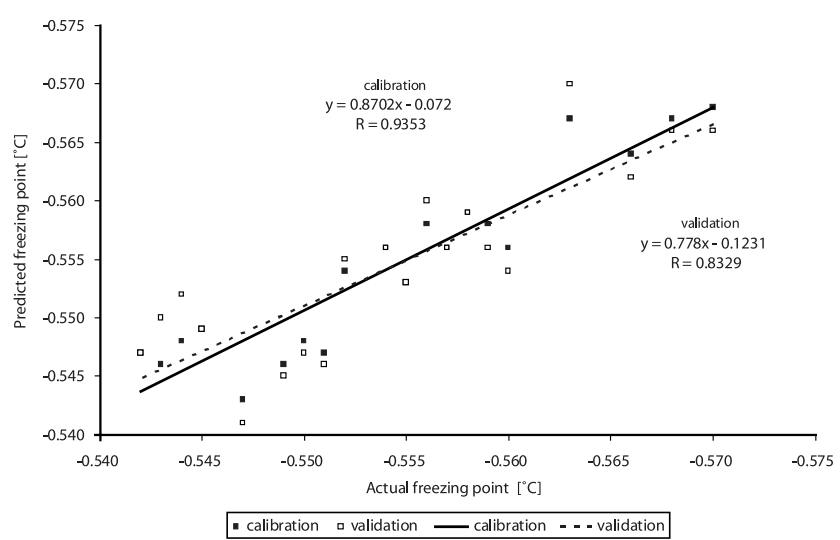

Fig. 6. Calibration and validation models of freezing point

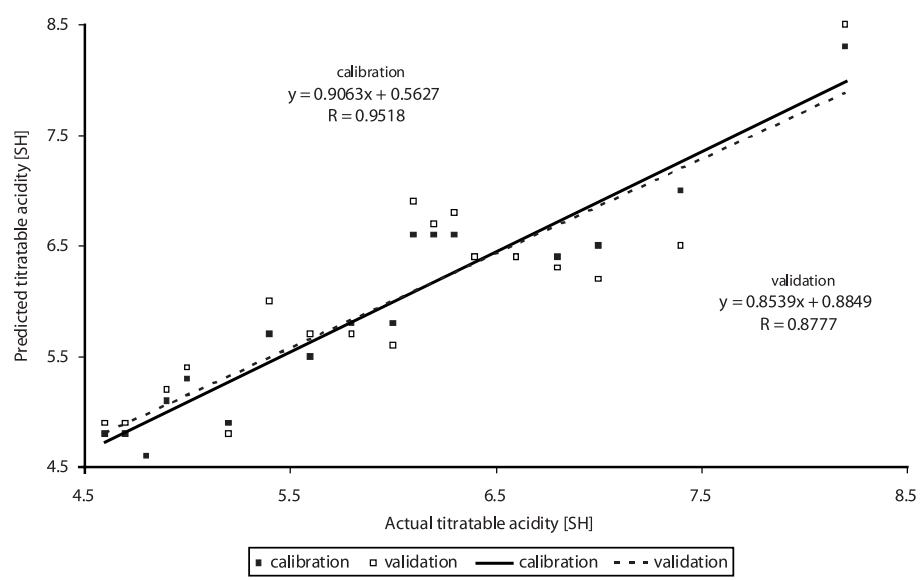

Fig. 7. Calibration and validation models of titratable acidity 


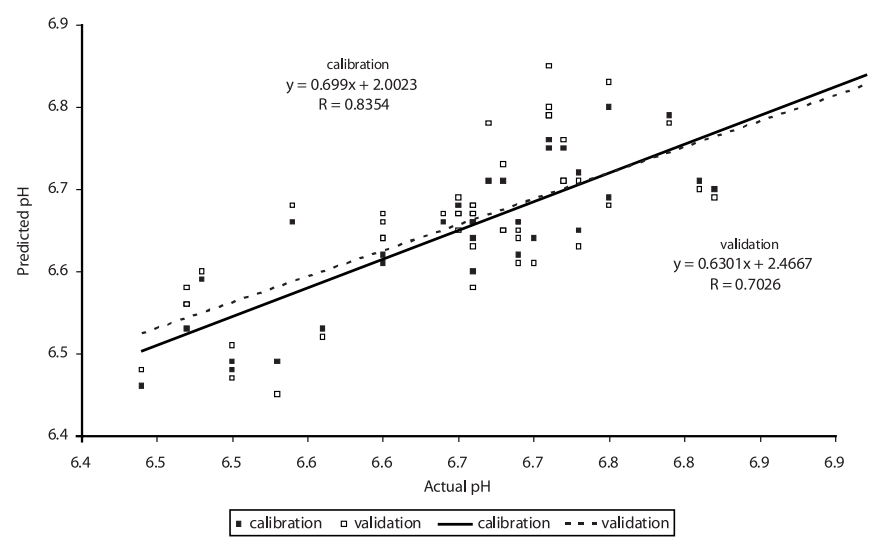

Fig. 8. Calibration and validation models of $\mathrm{pH}$

validation (SECV) at $0.050 \%$ for lactose and 0.076 for $\mathrm{pH}$. The highest SECV were found for titratable acidity at $0.469 \mathrm{SH}(R=0.878)$ and for total solids at $0.334 \%(R=0.899)$ (Table 2, Figs $1-8$ ).

The indirect method (the mid-infrared spectroscopy - analyzer Bentley) as a reference method for determination of protein, fat, lactose and non-fatty solids was used. This method can influence subsequent results of calibration models. Šustová et al. (2007) used the PROMILK instrument for the calibration of the FT-NIR spectrometer as a reference method for determination of true protein and casein in cow, ewe and goat milk. This method is based on the formation of an insoluble protein-dye complex, forming after the addition of excess Amido Black 10B to a buffered solution.

The error of the indirect method calibration for milk composition may be the reason of less robust models for protein and non-fatty solids contents. Less robust models were obtained for freezing point and titratable acidity.

Šustová et al. (2007) used FT NIR spectroscopy for determination of true protein and casein in goat milk. They obtained correlation coefficients of calibrations $(R)$ and standard errors of calibration (SEC) as follows: for true proteins $R=0.989, \mathrm{SEC}=0.06$ and for casein $R=0.890, \mathrm{SEC}=0.12$. The values of validations were for true protein $R=0.972$, $\mathrm{SECV}=0.09$ and for casein $R=0.814, \mathrm{SECV}=0.16$. These authors confirmed that near infrared spectroscopy enables an easy and quick control of milk composition, timely interventions in the production, and thus may improve the economics of dairy plants, in particular of cheese producers.

NIR reflectance technique for determination of the contents of protein, casein, total solids and somatic cell counts in goat milk was used also by Albanell et al. (2003). These authors performed analyses in unhomogenized and homogenized goat milk samples and they achieved high correlation coefficients which are comparable with our results. For homogenized milk, Albanell et al. (2003) found the following calibration and validation correlation coefficients: 0.98 and 0.97 for fat, 0.96 and 0.95 for protein and 0.94 and 0.93 for total solids. For unhomogenized milk, the values were: 0.98 and 0.97 for fat, 0.95 and 0.95 for protein and 0.95 and 0.95 for total solids. Šustová and Kuchtík (2007) found that results of calibration for somatic cells are not accurate (correlation coefficient of calibration 0.885 and correlation coefficients of validation 0.566 ).

Based on the assessment of the variable values of calibration coefficients of variation (CCV) and prediction coefficients of variation (PCV) (Jankovská and Šustová 2003; Albanell et al. 1999), very reliable models were developed (Table 2). The results were 
processed statistically using the STAT Plus software (Matoušková et al. 1992). No significant differences $(p=0.05)$ were found between the reference values and those calculated using FT-NIR.

Calibration models were obtained for determination of the contents of protein, fat, lactose, total solids, non-fatty solids, freezing point, titratable acidity and $\mathrm{pH}$ in the goat milk. The results were assessed based on the correlation between the reference and calibration equation calculated values and based on the standard errors of calibration and validation (SEC, SECV). For all of the monitored indicators, very reliable calibration models were developed. Crossvalidation pointed out the applicability of NIR spectrometer for the determination of basic components. FT-NIR spectroscopy presents a viable technique for rapid goat milk analysis. The models for freezing point and titratable acidity were less robust therefore FT-NIR spectroscopy is suitable only for screening determination of these indicators.

\section{Analýza kozího mléka pomocí NIR spektroskopie}

Cílem práce bylo využití blízké infračervené spektroskopie s Fourierovou transformací (FT-NIR) v kombinaci s metodou částečných nejmenších čtverců (PLS) pro stanovení obsahu bílkovin, tuku, laktózy, sušiny, tukuprosté sušiny, bodu mrznutí, titrační kyselosti a pH u 60 vzorků kozího mléka. Spektra byla naměřena v modu reflektance s transflektanční kyvetou o tloušt'ce vrstvy $0,1 \mathrm{~mm}$ ve spektrálním rozsahu $10000-4000 \mathrm{~cm}^{-1}$ se 100 scany. Pro sledované ukazatele byly vytvořeny kalibrační modely, které byly statisticky zhodnoceny na základě korelačních koeficientı̊ $(R)$ a směrodatných odchylek kalibrace (SEC). Pro bílkovinu byly zjištěny hodnoty $R=0,920$ a SEC $=0,094$, pro tuk $R=0,951$ a SEC $=0,124$, pro laktózu $R=0,997$ a SEC $=0,011$, pro sušinu $R=0,940$ a SEC $=0,260$, pro tukuprostou sušinu $R=0,873$ a SEC $=0,159$, pro bod mrznutí $R=0,935$ a SEC $=0,003$, pro titrační kyselost $R=0,952$ a SEC $=0,295$ a pro $\mathrm{pH} R=0,835$ a $\mathrm{SEC}=0,057$. Vytvořené kalibrační modely byly následně ověřeny pomocí cross-validace. Ze studie vyplývá, že FTNIR spektroskopie představuje vhodnou techniku pro rychlou analýzu základních složek kozího mléka.

\section{Acknowledgement}

This study was supported by Grant 6215712402 "Veterinary aspects of food safety and quality" of the Ministry of Education, Youth and Sports of the Czech Republic.

\section{References}

AGANGA AA, AMARTEIFÍO JO, NKILE N 2002: Effect of storage of lactation on nutrient composition of Tswana sheep and goat's milk. J Food Compos Anal 15: 533-543

ALBANELL E, CÁCERES P, CAJA G, MOLINA E, GARGOURI A 1999: Determination of fat, protein and total solids in ovine milk by near-infrared spectroscopy. J AOAC Int 82: 753-758

ALBANELL E, CAJA G, SUCH X, ROVAI M, SALAMAAAK, CASALS R 2003: Determination of fat, protein, casein, total solids, and somatic cell count in goat's milk by near-infrared reflectance spectroscopy. J AOAC Int 86: 746-752

ČSN 570530 1972: Metody zkoušení mléka a tekutých mléčných výrobků (Methods for testing of milk and milk products). Český normalizační institut, Praha, 100 p.

ČSN ISO 6731 1997: Mléko, smetana a zahuštěné neslazené mléko - stanovení obsahu celkové sušiny - referenční metoda (Milk, cream and evaporated milk - determination of total solids content - reference method). Český normalizační institut, Praha, 6 p.

ČSN 570536 1999: Stanovení složení mléka infračerveným absorpčním analyzátorem (Determination of milk composition by mid-infrared analyzer). Český normalizační institut, Praha, 12 p.

ČSN 570538 1998: Stanovení bodu mrznutí mléka pomocí mléčných kryoskopů (Determination of freezing point in milk - cryoscope method). Český normalizační institut, Praha, 6 p.

ČURDA L, KUKACKOVÁ O, NOVOTNÁ M 2002: Near-infrared spectroscopy and its application to milk and dairy products analysis. Chem Listy 96: 305-310

DÍAZ-CARRILLO E, MUÑOZ-SERRANO A, ALONSO-MORAGAA, SERRADILLA-MANRIQUE JM 1993: Near infrared calibrations for goat's milk components: protein, total casein, $\alpha$-, $\beta$ - and $\kappa$-casein, fat and lactose. J Near Infrared Spectrosc 1: 141-146 
JANKOVSKÁ R, ŠUSTOVÁ K 2003: Analysis of cow milk by near-infrared spectroscopy. Czech J Food Sci 21: $123-128$

LEE KA 2004: Applications of near infrared spectroscopy to food analysis. The NIR Spectrum 2: 11-16

MATOUŠKOVÁ O, CHALUPA J, CÍGLER M, HRUŠKA K 1992: STAT Plus - uživatelská př́ručka. VÚVeL, Brno, $168 \mathrm{p}$.

RU YJ, GLATZ PC 2000: Application of near infrared spectroscopy (NIR) for monitoring the quality of milk, cheese, meat and fish. Asian Austral J Anim Sci 13: 1017-1025

ŠUSTOVÁ K, KUCHTÍK J 2007: Analysis of goat's milk by FT near infrared spectroscopy. Acta Univ Agric Silvic Mendel Brun 4: 103-109

ŠUSTOVÁ K, RŮŽIČKOVÁ J, KUCHTÍK J 2007: Application of FT near spectroscopy for determination of true protein and casein in milk. Czech J Anim Sci 52: 284-291

TSENKOVA R, ATANASSOVA S, ITOH K, OZAKI Y, TOYODA K 2000: Near infrared spectroscopy for biomonitoring: Cow milk composition measurement in a spectral region from 1,100 to 2,400 nanometers. J Anim Sci 78: 515-522 